\title{
Towards a Model of Psychological Well- Being. The Role of Socioeconomic Status and Satisfaction with Income in Chile*
}

\author{
Hacia un modelo de Bienestar psicológico: el rol del nivel \\ socioeconómico y satisfacción con el ingreso en Chile
}

Recibido: 17 de junio de 2015 | Revisado: 5 de agosto de 2015 | Aceptado: 20 de septiembre de 2015

\author{
Pablo Vera-Villarkoel ** \\ KaREM Celis-Atenas \\ SEBASTIÁN LILLO \\ Daniela CONTRERAS
}

Centro de Innovación en Tecnologías de la Información para Aplicaciones Sociales (CITIAPS), Chile

Universidad de Santiago de Chile

NATAlia DíAZ-PARDO

JAVIER TORRES

SALVADOR VARGAS

JUAN CARLOS OYANEDEL

Universidad de Santiago de Chile, Santiago, Chile

DARIO PÁEZ

Universidad del País Vasco, España, Facultad de Administración y Economía, Universidad de Santiago de Chile

doi:10.11144/Javeriana.upsy14-3.tmpw

Para citar este artículo: Vera-Villarroel, P., CelisAtenas, K., Lillo, S., Contreras, D., Díaz-Pardo, N., Torres, J., ... Páez, D. (2015). Towards a model of psychological well-being. The role of socioeconomic status and satisfaction with income in Chile. Universitas Psychologica, 14(3), 1055-1066. http:// dx.doi.org/10.11144/Javeriana.upsy14-3.tmpw

Acknowledgements: This research was supported by FONDECYT project number 1140211, project PMIUSA 1204, Ministerio de Educación de Chile.

** Correspondence: Pablo Vera-Villarroel, Escuela de Psicología. Universidad de Santiago de Chile, USACH. Avenida Ecuador 3650, $3^{\circ}$ Piso. Santiago. E-mail: pablo.vera@usach.cl

\section{A B S T R A C T}

Association between indexes of socioeconomic status, satisfaction with income and status, and psychological well-being (PWB) was examined in a representative sample of Chileans. Results confirm a positive association between socioeconomic status and satisfaction with income and status and PWB. Associations were stronger with PWB facets related to relational, control and self-esteem processes, and weaker with purpose of life, growth and autonomy. Structural equation modeling confirmed a direct significant coefficient of socioeconomic status on PWB, as well as an indirect significant path through satisfaction with income and status. Control for satisfaction with socioeconomic status and purchase power reduced but did not eliminate the effect of socioeconomic status on PWB. Results are consistent with a direct effect model of socio-structural position on well-being, but also with the relevance of satisfaction with social position as an appraisal process to indicate high psychological well-being. Keywords

Psychological well-being; satisfaction with income and status

\section{RESUMEN}

Se estudió la asociación entre nivel socioeconómico, satisfacción con los ingresos, estatus económico, y el bienestar psicológico, en una muestra representativa de chilenos. Los resultados confirman una asociación positiva entre el nivel socioeconómico, la satisfacción con el ingreso, estatus económico y el bienestar psicológico. Las asociaciones fueron más fuertes con las dimensiones de bienestar psicológico, relaciones con el entorno, y autoestima, y más débil con las dimensiones de propósito con vida, crecimiento personal y autonomía. Modelo de ecuaciones estructurales confirmaron con indicadores de ajuste significativo la relación entre la situación socioeconómica 
y el bienestar psicológico, así como una trayectoria significativa indirecta a través de la satisfacción con los ingresos y el estatus económico. Al controlar el poder adquisitivo en su relación con satisfacción con el ingreso, redujo su efecto, pero no eliminó el efecto del nivel socioeconómico sobre el bienestar psicológico. Los resultados son consistentes con un modelo de efecto directo de la relación entre situación económica y bienestar. Se presenta la importancia de la satisfacción con el ingreso y el estatutos como predictores del bienestar psicológico

Palabras clave

Bienestar Psicológico; Satisfacción con los ingresos y estatus

\section{Introduction}

In this paper we examine the association of socioeconomic status (SES) with eudaimonic or psychological well-being. First, we examine evidence on the association between indexes of income, occupation, educational level and global SES on subjective and eudaimonic well-being. Second, evidence on the mediational role of appraisal or judgments of satisfaction with income and status is reviewed. This is one of the few studies to examine the relationship between SES and PWB - and the first to our knowledge in the Latin America sociocultural context.

Well-being has traditionally been defined from two perspectives (Ascorra et al., 2014; Marrero, González, \& Carballeira, 2014; Morales et al., 2014; Park, Petersen, \& Sun, 2013; Vazquez, 2013; Vera-Villarroel \& Celis-Atenas, 2014). The hedonic well-being (HWB) or subjective well-being (SWB) approach posits positive and negative affect and life satisfaction as main components (Chaves, Vazquez, $\&$ Hervas, 2013; Chavarria \& Barra, 2014; Figueiredo, Zanon, \& Koller, 2014; Ryan \& Deci, 2001; Moyano, Martínez, \& Muñoz, 2013, Von Humboldt \& Leal, 2014). Psychological well-being (PWB) is represented by Ryff's six-dimension structure of positive psychological functioning. Based on a review of mental health, clinical and life span developmental traditions and translating them to a scale, Ryff (1989) proposed autonomy, environmental mastery, personal growth, positive relations with others, purpose in life, and self-acceptance as core dimensions of well-being (Chitgian-Urzúa, Urzúa, \& Vera-Villarroel, 2013; Leal-Soto, Dávila, \& Valdivia, 2014;
Peréz-Aldeguer, 2014; Vera-Villarroel, Urzúa, Pavez, Celis-Atenas, \& Silva, 2012). This theoretically founded set of facets represents the core components of human flourishing. Factor analytic studies support the existence of these two different dimensions of well-being (Compton, Smith, Cornish, \& Qualls, 1996; Linley, Maltby, Wood, Osborne, \& Hurling, 2009) even if an overlap should be recognized between the hedonic and eudaimonic perspectives (Ryan \& Deci, 2001).

SES is often measured as a combination of education, income and occupation. It is commonly conceptualized as the social status or class of an individual or group. Higher social class is associated with privilege, power and control. There is clear evidence that lower socioeconomic status is associated with psychological distress, for instance $r=0.1$ with a new depressive episodes and $r=0.3$ with depression (Lorant et al., 2003) as well as with HWB, Dozens of studies and meta-analyses in different nations have revealed that socioeconomic status correlates with SWB, usually evaluated as satisfaction with life - r's around 0.17 in adults samples (Haring, Okum, \& Stcok, 1984; Diener, Suh, Lucas, \& Smith, 1999) and $r=0.17$ in a meta-analysis of elderly people (Pinquart \& Sorensen, 2000). Income, a facet of $\mathrm{SES}$, is related to SWB with an $r$ around 0.2 (Diener et al., 1999; Diener, Lucas, Schimmack, \& Helliwell, 2009). A study found a similar relation in Chile: $r$ $=0.21$ between incomes and satisfaction with life, using $n=220,000$ people in a representative sample (Vargas et al, 2015). Another found an $r=0.13$ and $r=0.04$ between income and happiness (Vera-Villarroel et al., 2012).

Increases in income are also related to increases in subjective well-being in at least two studies with lottery winners, and a panel study examining changes in income found positive effects of increases in happiness - at least at mid-term (Diener et al., 2009).

Data are more limited regarding the impact of SES on PWB. It seems reasonable to suggest, however, that SES has an important impact on facets like mastery and self-acceptance. Studies show that SES is related to the internal locus of control (Mirowsky, Ross, \& Van Willingen, 1996); similar to mastery, SES is also related to self-esteem $-r=0.08$ in a 
general meta-analysis (Twenge \& Campbell, 2002) and $r=0.17$ in a meta-analysis of elderly people (Pinquart \& Sorensen, 2000). Occupation is closely tied to socioeconomic level and job characteristics related to type of occupation, like autonomy and complexity, which are highly correlated with social class and are positively related to PWB (Kohn \& Schooler, 1983 in Miller-Loesi, 1995). Some data support that PWB is related to high SES (Ryff et al., 1999), a correlation of 0.3 was found in Portugal between education, SES and Ryff's scale score (Fernandes, Vasconcelos-Raposo, \& Brustad, 2012). In terms of the association between income and PWB or eudaimonic well-being, using data collected over 29 years, Kaplan, Shema, and Leite (2008) found that higher income and increases in income over time were associated with higher scores in purpose in life, self-acceptance, personal growth, and environmental mastery, and these scores were lower for those with a lower average income, lower increases in income and higher reception of social benefits (autonomy was unrelated to income level and changes) (Kaplan et al., 2009). Studies in lay conceptions of well-being in Chile have found that the lower classes emphasize harmony, security and control of social milieu, whereas the upper classes emphasize more purpose of life and personal growth as aspects of happiness - sharing at the same time the importance of security and a controlled life (Programa de las Naciones Unidas para el Desarrollo [PNUD], 2012), High-status people have supposedly fulfilled more basic needs of security, control and relational (Ryan \& Deci, 2001) and can therefore stress more self-realization and attribution of meaning, growth and autonomy in PWB. Thus, it is to be expected that differences between the upper and lower classes will be strong in facets related to purpose of life, growth and probably autonomy.

Globally we can expect that high social status, defined as high income and belonging to the upper class, occupational status and high education should be related to PWB. SES is related to HWB and PWB, primarily because it is obviously related to a better quality of life. This is consistent with a direct effect of social status (i.e. high occupation, income, education and belonging to the upper social class) on PWB. However, income is correlated more strongly with well-being than education (Pinquart \& Sorensen, 2000) and income is strongly related to life satisfaction, a more cognitive facet of SWB than with affect balance of positive and negative emotions, a more affective facet of SWB (Agrawal $\&$ Harter, 2011; Diener et al., 2009). Since PWB is strongly related to attribution of meaning and cognitive judgment, we can expect that correlations between SES and PWB will be higher than with HWB - and secondly that occupational status will be more strongly related to PWB than education.

Second, SES decreases stress, reinforces social integration and social support, affords accomplishment of needs like autonomy, self-esteem and self-determination, and creates resources to cope with life changes. These processes facilitate a positive appraisal of the self and the world. Confirming these ideas, on the one hand current income correlated positively with satisfaction with pay incomes with $r=0.29$ in a meta-analysis (Williams, McDaniel, \& Nguyen, 2006), while satisfaction with income correlated more strongly than actual income with happiness in a representative sample of young Spanish adults (Javaloy, 2007), and satisfaction with income mediated the effect of income on satisfaction with life (Diener et al., 2009). In the same vein, data suggest that more subjective indices of status like sociometric status - self-perceived respect and admiration in front of others - had a stronger effect on SWB than SES (Anderson, Kraus, Galinsky, \& Keltner, 2012). This suggests a total or partial mediational role of satisfaction with income and status between SES and PWB.

Finally, some authors posit an asymptotic association between income and well-being. Above a certain level of income that can fulfill basic needs of survival and security, increases in earning do not likely reinforce well-being; however, a logarithmic transformation of income is linearly related to well-being, suggesting that higher increases are needed to reinforce well-being when people receive higher salaries (Diener et al, 2009). These results suggest that differences in PWB between the lower, middle and upper classes are stronger than between the last ones. 
In conclusion, this study contrasts the direct and indirect "positive" effect of SES on PWB, the total or partial mediational role of satisfaction with status and income on PWB, effect size comparisons of class differences in PWB dimensions (expected to be higher in autonomy, purpose of life and growth) as well as an asymptotic (versus linear) association between SES and PWB.

\section{Method}

\section{Participants}

The total sample was composed of 620 people from Santiago, Chile: 206 men and 413 women, aged between 18 and 93 years, with a mean of 33.1 years and a standard deviation (SE) of 13.72 years. The intentional selection of the sample included volunteers, and the only exclusion criterion was to have a diagnosed mental pathology.

Participants were not offered any type of remuneration. Sample mortality was estimated to be $15 \%$.

\section{Procedure}

The participants were contacted in the public and private spheres, and those who agreed to participate in the study signed an informed consent and answered questionnaires that measured indicators of happiness and purchasing power. Additionally, each participant was asked about sociodemographic variables, e.g. gender, age, education level, occupational level. For the optimal administration of the instruments, the questionnaires were explained and read together with each participant and during their application help was provided in the event of queries regarding classifying occupational level.

\section{Instruments}

\section{The following instruments were used:}

Happy Life Inventory, facets of satisfaction with income and status by Kim, Kim, Cha, and Lim (2007).
This instrument evaluates different indicators in the context of people's daily lives in relation to what makes them happy through 16 dimensions. The original version had 156 items, evaluated on a 6-point Likert scale, going from describes me completely to doesn't describe me at all. For this study the original instrument was translated by a graduate of English language studies, and based on the researchers' criterion those items suitable to the country's sociocultural context were selected; the scale was finally composed of 89 items. In the original version, the metric properties were reported as being adequate with a Cronbach's alpha between 0.7 and 0.9 (Kim et al., 2007).

This study dealt with the dimensions of satisfaction with purchasing power and satisfaction with status. Each dimension contained 6 items, including for example, "I can afford to buy what I want", "I think I live well materially" A Cronbach's alpha of 0.7 was obtained for satisfaction with purchasing power and 0.69 with satisfaction with status.

Psychological Well-Being Ryff (1989) developed a theoretically-based self-report inventory designed to measure six dimensions of PWB. The six dimensions were self-acceptance, environmental mastery, purpose in life, positive relations with others, personal growth and autonomy. Respondents rated each of the 30 items on a 1 (strongly disagree) to 6 (strongly agree) response scale using the Spanish version. Internal consistency, test-retest reliability, confirmatory factor analysis and concurrent criterion validity are satisfactory for the Spanish version (Díaz et al., 2005). The adaptation of he instrument in Chile showed adequate indicators both in reliability and validity (Chitgian -Urzúa et al., 2013; Vera-Villarroel et al., 2013). In this sample the reliability of the six scales was satisfactory (as $=0.6$ to 0.8 ) and the composite PWB score reliability was satisfactory - Cronbach's alpha of 0.88 .

Occupational Level: Occupational level was evaluated by means of six response options: occasional casual worker, unskilled worker, skilled worker, administrative employee, mid-level executive, top executive, which are categories used 
regularly in the Chilean context (Adimark, 2000).

Education level: The following options were considered for education level: incomplete elementary, complete elementary, incomplete high school, complete high school, incomplete university, complete university, and graduate studies.

Socioeconomic level: Social class was classified according to participants' occupation and educational level on the basis of a combination of both variables in 6 groups: A (Very high), B (High), CA (Middle-High), CB (Middle), D (Middle-Low), E (Low) and F (Very low), which are categories used regularly in the Chilean context (Adimark, 2000).

\section{Data Analysis}

To contrast associations between SES and SES components, satisfaction with purchasing power and status with PWB, as well as between objectives and subjective SES indexes, correlations were used. To contrast the asymptotic hypothesis, an analysis of variance, contrast of linear and nonlinear effects and Bonferroni's post hoc means comparisons were performed among the three levels of SES and PWB facets. Finally, a structural equation model and mediational analysis were used to contrast direct, indirect and mediational effects of SES, satisfaction with purchasing power and status on PWB. The analyses were performed with SPSS.20, with Amos and with Preacher and Hayes procedures.

\section{Results}

\section{Correlations between SES, Satisfaction with Purchase and Status and PWB}

As expected, PWB showed significant correlations with SES $r_{(602)}=0.232, p<0.001$, correlated with satisfaction social status, $r=0.26$, and purchasing power, $r=0.27$. SES also correlated with satisfaction with purchasing power, $r=0.75$, and satisfaction with social status, $r=0.26$. Facets of SES also correlated with PWB: educational level, $r=0.21$ and occupational level, $r=0.17$, both $p<0.01$.

\section{Means Comparison between SES Levels and PWB}

An analysis of variance contrasted if there was a linear or nonlinear relationship between social classes into three categories. Six SES levels were reorganized into three classes to have clearly distinctive SES conditions with satisfactory degrees of freedom. Linear and nonlinear effects were contrasted using post hoc differences between groups and applied equally.

In the dimensions of personal growth, positive relationships, purpose in life, self-acceptance, environmental mastery and autonomy, PWB differs between low, SES medium and high SES. Importantly, no differences were found between the medium and high levels of SES. The linear effect was stronger than the nonlinear in all analyses. Differences between high, middle and lower class

TABLE 1

Correlations between Education, Occupation, SES, Satisfaction with Income, Status and Psychological Well-Being

\begin{tabular}{lccccc}
\hline & Education Level & $\begin{array}{c}\text { Occupational } \\
\text { Group }\end{array}$ & SES & $\begin{array}{c}\text { Satisfaction with } \\
\text { Social Status }\end{array}$ & $\begin{array}{c}\text { Satisfaction with } \\
\text { Purchasing Power }\end{array}$ \\
\cline { 2 - 6 } Occupational Group & $0.4^{* * *}$ & 1 & & & \\
SES & $0.84^{* *}$ & $0.84^{* *}$ & 1 & & \\
Sat. Social Stat. & $0.14^{* *}$ & $0.12^{* *}$ & $0.16^{* *}$ & 1 & \\
Sat. Purchasing Power & $0.14^{* *}$ & $0.12^{* *}$ & $0.17^{* *}$ & $0.75^{* *}$ & 1 \\
Ryff Total Score & $0.21^{* *}$ & $0.17^{* *}$ & $0.24^{* *}$ & $0.26^{* *}$ & $0.27^{* *}$ \\
\hline
\end{tabular}

$* * p<0.01$.

Source: own work 
TABLE 2

Descriptive Statistics for Facets of Psychological Well-Being by Socioeconomic Status

\begin{tabular}{|c|c|c|c|c|c|c|c|}
\hline & \multicolumn{2}{|c|}{ Low (1) } & \multicolumn{2}{|c|}{ Middle (2) } & \multicolumn{2}{|c|}{ Upper (3) } & \multirow[b]{2}{*}{ Post hoc } \\
\hline & M & SE & M & SE & M & SE & \\
\hline Self-Acceptance & 4.73 & 0.93 & 5.02 & 0.73 & 5.08 & 0.78 & $1<2,3$ \\
\hline Positive Relationships & 4.29 & 0.99 & 4.58 & 0.95 & 4.61 & 1.02 & $1<2,3$ \\
\hline Autonomy & 3.85 & 0.76 & 3.97 & 0.79 & 4.05 & 0.75 & $1=2=3$ \\
\hline Mastery & 4.34 & 0.9 & 4.69 & 0.79 & 4.8 & 0.89 & $1<2,3$ \\
\hline Personal growth & 5.18 & 0.91 & 5.39 & 0.66 & 5.34 & 0.73 & $1<2,3$ \\
\hline Purpose in Life & 4.76 & 1.02 & 4.97 & 0.79 & 5.01 & 0.9 & $1<2,3$ \\
\hline Ryff Total Score & 4.53 & 0.68 & 4.77 & 0.55 & 4.82 & 0.59 & $1<2,3$ \\
\hline
\end{tabular}

Note. < Significant differences between groups "post hoc".

Source: own work

using Pearson r's as estimate showed an effect size of $r=0.19$ for global PWB and mastery, self-esteem $r=0.16$, positive relationships with others $r$ $=0.13$, life purpose, $r=0.11$, growth, $r=0.095$, autonomy $r=0.09$.

However, Bonferroni's test indicated that the lower classes had lower PWB levels than the middle and upper classes in all dimensions but autonomy. Bonferroni also found no significant differences between the middle and upper classes.

\section{Structural Model of SES, Satisfaction with Purchase Power and with Status and PWB}

First, we contrasted a model in which SES scores were the external explanatory factor, and satisfaction with income or purchase power and status scores were dependent on SES, but at the same time mediates the influence of the latter on PWB. Structural equation modeling was also used with Amos. The estimation procedure applied was maximum likelihood, which tests the hypothesis of equality of covariance matrices of the theoretical and empirical models. Given the lack multivariate normally, various robust indices that adjusted for non-normality were used to assess model fit, both chi-square statics and goodness-of-fit criteria. Given the sensitivity of the $\chi^{2}$ test to sample size and our relatively large sample, it was deemed inappropriate to interpret the $\chi^{2}$ statics, and thus more attention was paid to incremental fit measures such as the comparative fit index (CFI) (Scher-
melleh-Engel, Moosbrugger, \& Muller, 2003) as well as the Akaike information criterion (AIC), which serves to compare alternative models, both nested and nested. An array of indices was used to asses model fit: a. the chi-square value of statistical fitting of the empirical model, which is expected to have low values (be non-significant); b) the CFI and non-normed fit index (NNFI) as indicators of goodness-of-fit, with values over 0.9 considered acceptable, and values greater than 0.95 representing a good fit; and c) the root meansquare error of approximation (RMSEA), a value of under 0.05 being recommended as indicating good fit, and reasonable fit at values between 0.05 and 0.08 (Bentler, 1990; Bentler \& Bonnet, 1980; Hu \& Bentler, 1999; Jöreskong \& Sörbom, 1993). Whereas the NFI is still affected by sample size, the CFI is less sensitive in that regard.

An Amos analysis found that Ryff's theoretical dimensions and structural relations fit well with the data. The results supported the model that showed an acceptable fit: $\chi^{2}=168.3, p=$ $0, \chi^{2} / g l=5.8, \mathrm{CFI}=0.92$, IFI $=0.92$, RMSEA $=0.088$.

In order to test the mediation effects of SES on well-being through satisfaction with status (ST) and perceived purchasing power (PP), using gender and age as covariates, we used the SPSS macro for bootstrapping indirect effects (Hayes $\&$ Preacher 2011; Preacher \& Hayes 2008), which provides indirect effect estimates for multiple mediators, standard errors (SEs), and the confi- 


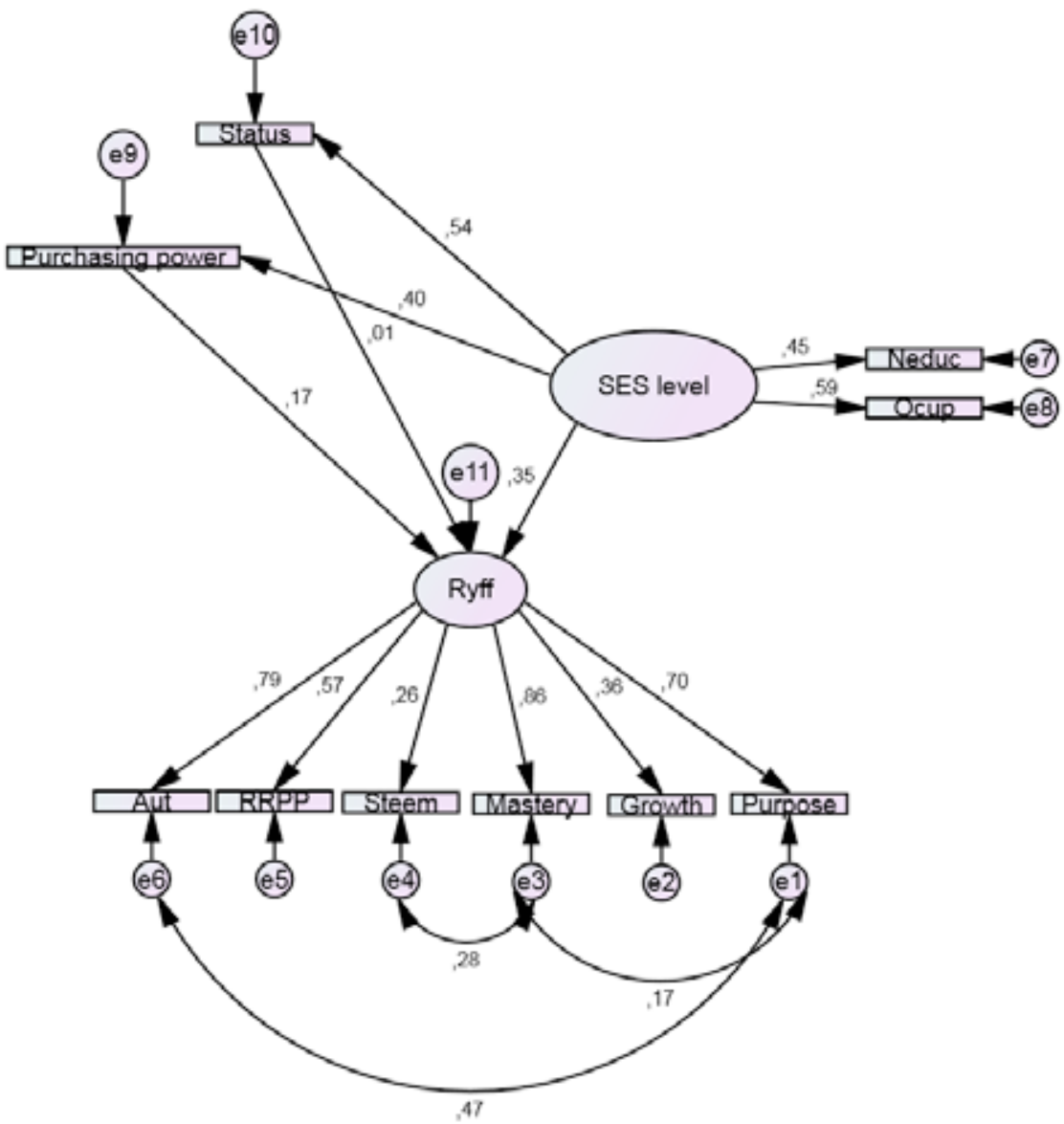

Figure 1. Structural Equation Model SES Level, Satisfaction with Status, with Purchase Power and Psychological Well-Being.

Source: own work

dence intervals (CIs) derived from the bootstrap distribution. Bootstrapped CIs are superior to more traditional ways of estimating standard errors of indirect effects (Preacher \& Hayes 2008). An indirect effect is significant if the CI does not include a 0 value. In order to facilitate the comparison of coefficients, all the variables were standardized with descriptive procedures of SPSS 20.

As observed in Fig. 2, all the direct and total effects of SES, ST, PP on Ryff's scale were significant, consistent with previous analyses. There was a significant indirect effect of SES on well-being through satisfaction with $\mathrm{PP}(B=0.04, \mathrm{SE}=0.01$, CI $[0.01,0.07])$ as well as through ST $(B=0.03$, $\mathrm{SE}=0.01$, CI $[0.01,0.06])$.

\section{Discussion}

This is one of the few studies confirming differences in PWB associated with SES. Results show an association between PWB and specific and global SES indices of around $0.20-0.25$ - as found in studies with SWB. Also as expected effect size is strong for the association between SES and PWB (effect size $r=0.19$ ) than with Lyubomirsky scale found in a previous study $(r=0.13$ and $r=0.04)$ ) (see Vera-Villarroel et al., 2012). Results confirm that SES associates more strongly in the same with eudaimonic well-being as evaluated by Ryff's scale than with HWB. This means that the influence is greatest in the aspects of personal growth, sense of life, positive relations with others, self-esteem, autonomy 
Figure 2. Mediational Analysis.

Note. a, b, c, d e and c' standardized coefficients Process Preacher and Hayes.

$* * p<0.001 ; * p<0.05$.

Source: own work

and control of the means of well-being - explaining around $2 \%$ of variance - than the influence on $\mathrm{HWB}$, which explains around $1 \%$ of the variance. Globally, results confirm the notion that interactions and social structure influence eudaimonic well-being more than HWB, probably by means of the sociocognitive processes of attribution of meaning (Bilbao, Paez, Da Costa, \& Martinez, 2013; de la Cruz-Sanchez, Feu , \& Vizuete-Carrizosa 2013).

The results of this study indicate that there are higher levels of PWB in people of higher occupational status, education level in the upper classes; and people with a high self-perception of their purchasing power and social status consistent with that proposed by Ball and Chernova (2008) and a previous study on SWB (Vera-Villarroel et al., 2012).

Mixed results were found regarding the linear or asymptotic effect of SES on PWB. On the one hand, the linear effect was stronger than the nonlinear effect in all the analyses. On the other, consistent with an asymptotic relationship the lower class had lower PWB levels than middle and upper class, although there were no differences between them. This suggests that reaching the level of the middle class, an increase in social status does not reinforce PWB.

Differences between the high, middle and lower classes showed an effect size between $r=0.19$ for global PWB and mastery, $r=0.16$ for self-esteem, $r=0.13$ for positive relationships with others, $r=$ 0.11 for life purpose, $r=0.095$ for growth and $r$ $=0.09$ for autonomy. These results are consistent with previous studies and meta-analyses (Diener et al., 2009), but the association between SES and self-esteem was stronger in Chile than in the USA (Twenge \& Campbell, 2002). These stronger differences are probably related to the asymmetric, classist and hierarchical nature of Chilean culture (PNUD, 2012). These results are at odds with the idea that SES should be strongly related to differences in more complex needs like self-determination and PWB facets like purpose of life, autonomy and growth. In fact, differences are stronger in facets related to more basic needs like relational, control and self 
enhancement needs rather than to self-actualization needs. The low association between autonomy and SES than with others facets are consistent with the study by Kaplan et al. (2009).

Mediation analyses demonstrated that SES predicted PWB through the indirect effects of sense of status and satisfaction with purchase power or income. However mediation is only partial and SES maintains a significant effect on PWB, controlling for satisfaction with income and status. These results are in line with a "realistic" appraisal and reflect effects of social reality on well-being.

\section{Conclusions}

This study confirms a positive association between SES, satisfaction with income and status and PWB, with effect sizes around $r=0.20$, Associations are stronger with PWB facets related to relational, control and self-esteem processes, and weaker with purpose of life, growth and autonomy. The lower classes reported lower levels of PWB than the middle and upper classes, which did not differ between them, consistent with an asymptotic relationship between social status and well-being, Structural equation modeling confirmed a direct significant coefficient of SES (occupation and educational level) on PWB, as well as an indirect significant path through satisfaction with income and status. Results are in keeping with a model of direct effect of sociostructural position on well-being, but also with relevance of satisfaction with social position as an appraisal process conducive to high psychological well-being.

\section{References}

Adimark. (2000). El nivel socio económico Esomar. Manual de Aplicación. Extraído de http://www.microweb. $\mathrm{cl} / \mathrm{idm} /$ documentos/ESOMAR.pdf

Agrawal, S., \& Harter, J. (2011). Wellbeing meta-analysis: A worldwide study of the relationship between the five elements of wellbeing and life evaluation, daily experiences, health, and giving. Washington DC: Gallup Press.
Anderson, C., Kraus, M., Galinsky, A., \& Keltner, D. (2012). The local-ladder effect: Social status and subjective well-being. Psychological Science, 23(7), 764-771.

Ascorra, P., López, V., Bilbao, M. A., Correa, T., Guzmán, J., Moraga, V., \& Olavarría, D. (2014). Relación entre el bienestar social de profesores y el nivel de autonomía y tamaño de escuelas municipalizadas chilenas. Terapia Psicológica, 32(2), 121-132.

Ball, R.E. \& Chernova, K. (2008). Absolute Income, Relative Income, and Happiness. Social Indicators Research, 88, 497-529

Bentler, P.M. (1990), "Comparative Fit Indexes in Structural Models,” Psychological Bulletin, 107 (2), 238-46.

Bentler, P.M. \& Bonnet, D.C. (1980), "Significance Tests and Goodness of Fit in the Analysis of Covariance Structures," Psychological Bulletin, 88 (3), 588-606.

Bilbao, M. -A., Paez, D., Da Costa, S., \& Martinez, G. (2013). Extreme life-changing events, impact on basic beliefs and post-stress growth: Why positive events reinforce eudaimonic wellbeing more strongly than negative events undermine it. Terapia Psicológica, 31(1), 127-139.

Chaves, C., Vazquez, C., \& Hervas, G. (2013). Benefit finding and well-being in children with threatening illnesses: An integrative. Terapia Psicológica, 31(1), 59-68.

Chavarria, M. P., \& Barra, E. (2014). Satisfacción vital en adolescentes: relación con autoeficacia y el apoyo social percibido. Terapia Psicológica, 32(1), 41-46.

Chitgian-Urzúa, V., Urzúa, A., \& Vera-Villarroel, P. (2013). Análisis preliminar de las Escalas de Bienestar Psicológico en población chilena. Revista Argentina de Clínica Psicológica, 22(1), 5-14.

Compton, W., Smith, M., Cornish, K., \& Qualls, D. (1996). Factor structure of mental health measures. Journal of Personality and Social Psychology, 71(2), 406-413.

Díaz, D., Rodríguez-Carvajal, R., Blanco, A., MorenoJiménez, B., Gallardo, I., Valle, C. \& Van Dierndonck, D. (2006). Adaptación española de las 
Escalas de Bienestar Psicológico de Ryff. Psicothema, 18, 572-577.

de la Cruz-Sanchez, E., Feu, S., \& Vizuete-Carrizosa, M. (2013). El nivel educativo como factor asociado al bienestar subjetivo y la salud mental en la población española. Universitas Psychologica, 12(1), 31-40.

Diener, E., Lucas, R., Schimmack, U., \& Helliwell, J. (2009). Well-being for public policy. Oxford; Oxford University Press.

Diener, E., Suh, E., Lucas, R., \& Smith, H. (1999). Subjective well-being: Three decades of progress. Psychological Bulletin, 125(2), 276-302.

Fernandes, H., Vasconcelos-Raposo, J., \& Brustad, R. (2012). Factors associated with positive mental health in a Portuguese community sample: A look through the lens of Ryff's psychological wellbeing model. In V. Olisah (Ed.), Essential notes in psychiatry (pp. 495-514). Rijeka, Croatia: In Tech.

Figueiredo, B., Zanon, C., \& Koller, S. (2014). Validación y propiedades psicométricas de la versión brasileña de la Escala de Felicidad Subjetiva. Universitas Psychologica, 13(1), 17-24.

Haring, M., Okun, M., \& Stock, W. (1984). A quantitative synthesis of literature on work status and subjective well-being. Journal of Vocational Behavior, 25, 316-324.

Hu, L.T. \& Bentler, P.M. (1999), "Cutoff Criteria for Fit Indexes in Covariance Structure Analysis: Conventional Criteria Versus New Alternatives," Structural Equation Modeling, 6 (1), 1-55.

Javaloy, F. (2007). Bienestar y felicidad de la juventud española. Instituto de la juventud: Barcelona, España

Jöreskog, K. \& Sörbom, D. (1993), LISREL 8: Structural Equation Modeling with the SIMPLIS Command Language. Chicago, IL: Scientific Software International Inc

Kaplan, G.A., Shema, S.J., \& Leite, C.M. (2008). Socioeconomic determinants of psychological well-being: The role of income, income change, and income sources during the course of 29 years. Annals of Epidemiology, 18(7), 531-537.

Kim, M., Kim, H., Cha, K., \& Lim, J. (2007). What makes Korean happy? Exploration on the structure of happy life among Korean adults. Social Indicators Research, 82(2), 265-286.
Leal-Soto, F., Dávila Ramírez, J., \& Valdivia, J. (2014). Bienestar psicológico y prácticas docentes con efectos motivacionales orientadas al aprendizaje. Universitas Psychologica, 13(3), 1037-1046.

Linley, P., Maltby, J., Wood, A., Osborne, G., \& Hurling, R. (2009). Measuring happiness: The higher order factor structure of subjective and psychological well-being measures. Personality and Individual Differences, 47(8), 878-884.

Lorant, V., Deliège, D., Eaton, W., Robert, A., Philippot, P., \& Ansseau, M. (2003). Socioeconomic inequalities in depression: A meta-analysis. American Journal of Epidemiology, 157(2), 98-112.

Miller-Loesi, K. (1995). Comparative social psychology: Crosscultural and cross national. In K. S. Cook, G. A. Fine \& J. S. House (Eds.), Sociological perspectives on social psychology (2d. ed., pp. 397-420). Boston: Prentice Hall.

Mirowsky, J., Ross, C., \& Van Willigen, M. (1996). Instrumentalism in the land of opportunity: Socioeconomic causes and emotional consequences. Social Psychology Quarterly, 59(4), 322-337.

Marrero, R., González, J., \& Carballeira, M. (2014). Relación entre bienestar subjetivo, optimismo y variables sociodemográficas en estudiantes universitarios de la Universidad de San Luis Potosí en México. Universitas Psychologica, 13(3), 1083-1098.

Morales, M., López, V., Bilbao, M. A., Villalobos, B., Oyarzún, D., Olavarrìa, D., ... Ascorra, P. (2014). El papel mediador de la capacitación docente en el manejo de la violencia escolar sobre el bienestar social de profesores. Terapia Psicológica, 32(2), 217-226.

Moyano, N., Martínez, M., \& Muñoz, M. (2013). Propiedades psicométricas de la Escala de Satisfacción con la Vida de Diener. Revista Argentina de Clínica Psicológica, 22(2), 161-168.

Park, N., Peterson, C., \& Sun, J. (2013). La psicología positiva: investigación y aplicaciones. Terapia Psicológica, 31(1), 11-19.

Peréz-Aldeguer, S. (2014). Los efectos del canto coral sobre el bienestar psicológico en adultos mayores. Revista Argentina de Clínica Psicológica, 23(3), 199-208.

Programa de las Naciones Unidas para el Desarrollo. (2012). Desarrollo humano en Chile. Bienestar sub- 
jetivo: el desafí de repensar el desarrollo [Subjective well-being: The challenge of thinking development]. Santiago: Author.

Pinquart, M., \& Sörensen, S. (2000). Influences of socioeconomic status, social network, and competence on subjective well-being in later life: A meta-analysis. Psychology and Aging, 15(2), 187-224.

Ryan, R., \& Deci, E. (2001). On happiness and human potentials: A review of research on hedonic and eudaimonic well-being. Annual review of psychology $(52,141-166)$.

Ryff, C. (1989). Happiness is everything, or is it? Explorations on the meaning of psychological well-being. Journal of Personality and Social Psychology, 57(6), 1069-1081.

Ryff, C., Magee, W., Kling, K., \& Wing, E. (1999). Forging macro-micro linkages in the study of psychological well-being. In C. Ryff \& V. Marshall (Eds.), The self and society in aging processes (pp. 247-278). New York: Springer.

Schermelleh-Engel, K., Moosbrugger, H., \& Müller, H. (2003). Evaluating the fit of structural equation models: Test of significance and descriptive goodness-of-fit measures. Methods of Psychological Research - Online, 8(2), 23-74

Twenge, J. M., \& Campbell, W. K. (2002). Self-esteem and socio-economic status: A meta-analytic re- view. Personality and Social Psychology Review, 6(1), 59-71.

Vazquez, C. (2013). Psicología positiva: introducción al número especial. Terapia Psicológica, 31(1), 5-10.

Vera-Villarroel, P., \& Celis-Atenas, K. (2014). Afecto positivo y negativo como mediador de la relación optimismo y salud: evaluación de un modelo estructural. Universitas Psychologica, 13(3), 10171026.

Vera-Villarroel, P., Urzúa, A., Silva, J., Pavez, P., Celis - Atenas, K. (2013). Escala de Bienestar de Ryff: Análisis Comparativo de Los Modelos Teóricos en Distintos Grupos de Edad. Reflexão e Crítica, 26(1), 106-112.

Vera-Villarroel, P., Celis-Atenas, K., Pavez, P., Lillo, S., Bello, F., Díaz, N., \& López, W. (2012). Money, age and happiness: Association of subjective wellbeing with socio-demographic variables. Revista Latinoamericana de Psicología, 44(2), 155-163.

Vera-Villarroel, P., Urzúa, A., Pavez, P., Celis-Atenas, K., \& Silva, J. (2012). Evaluation of subjective well-being: Analysis of the Satisfaction with Life Scale in the Chilean population. Universitas Psychologica, 11(3), 719 -727.

Von Humboldt, S., \& Leal, I. (2014). ¿Qué influye en el bienestar subjetivo de los adultos mayores? Una revisión sistemática de la literatura. Revista Argentina de Clínica Psicológica, 23(3), 219-230. 
